\title{
Jacek Nowakowski
}

\section{Dialog z tradycją malarską w literackiej i filmowej twórczości Lecha Majewskiego*}

ABSTRACT. Nowakowski Jacek, Dialog z tradycja malarska w literackiej i filmowej twórczości Lecha Majewskiego [Dialogue with a painting tradition in the literary and film work of Lech Majewski]. „Przestrzenie Teorii” 9. Poznań 2008, Adam Mickiewicz University Press, pp. 93106. ISBN 978-83-232-1917-0. ISSN 1644-6763.

This article presents Lech Majewski's works in the context of the intersemiotic translation: how the world painting functions in the literature and films of this author. Majewski attempts to make dreams of the modern synthesis of arts come true and in this he reminds of the activities of his Renaissance master, Leonardo da Vinci. This Polish artist by means of the painting tradition (both works as well as fragments of painters' biographies), set in the context of other media (literature, theatre, film) wants to create a modern, intermediate garden of arts whose central topic is the vision of paradise. It can be understood as a place of existence of heroes of his works and metaphorically - the language of art which the art uses freely uses various materials and media.

Twórczość Lecha Majewskiego - pisarza, kompozytora, reżysera filmowego i teatralnego $\mathrm{z}$ trudem daje się ogarnąc za pomocą jednego, syntetyzującego spojrzenia. Chciałbym się przyjrzeć przede wszystkim jej dwóm wymiarom - pisarskiemu i filmowemu - w kontekście pojawiających się w niej nawiązań do malarstwa europejskiego i światowego. Interesować mnie będzie nie tylko dialog z tradycją, widoczny poprzez sieć powiązań tematycznych, estetycznych i filozoficznych, ale także to, w jaki sposób współczesny artysta świadomie wykorzystuje różne media, charakteryzujące się swoistym systemem znakowym, co ma swoje konsekwencje w tym dialogu. Zajmę się w tym przypadku nie tylko transpozycją słowa na obraz, ale zwłaszcza procesem odwrotnym: jak obraz malarski funkcjonuje w literaturze, jak zostaje poddany werbalizacji, oraz jak funkcjonuje w utworze filmowym - swoistej wizualizacji.

Patronem inspiracji malarskich autora Rycerza zdaje się być Leonardo da Vinci. Uprawnia do takiej filiacji nie tylko szereg autokomentarzy Majewskiego (autor jest pod tym względem twórcą bardzo szczodrym), nie tylko oczywisty wewnątrztekstowy dialog $\mathrm{z}$ renesansowym

"Artykuł jest wersją referatu wygloszonego na Interdyscyplinarnej Konferencji Naukowej Dramatyczność i dialogowość w kulturze zorganizowanej przez Pracownię Estetyki Literackiej Uniwersytetu im. Adama Mickiewicza i Zakład Teorii Literatury i Poetyki Uniwersytetu Warszawskiego, Kołobrzeg 16-19 października 2007. 
artystą, ale przede wszystkim rodzaj postawy twórczej Majewskiego, nawiązującej do uniwersalizmu swojego poprzednika. Pozornie niewiele przemawia na korzyść takiej paraleli. Stosunek polskiego twórcy do innych artystów-malarzy wydaje się, ze względu na rozległość zainteresowań, nie posiadać jednego mianownika. Na gruncie filmowym będą to przykładowo - odwołania do sposobu kompozycji i oświetlenia znanego z włoskiego quatrocenta w Rycerzu; w Basquiacie, którego Majewski był współscenarzystą i producentem, przedstawienie kariery dwudziestowiecznego malarza i autora graffiti; w Angelusie natomiast ukazanie losów i twórczości malarzy związanych z janowską grupą okultystyczną - Teofila Ociepki i Erwina Sówki; w Ogrodzie rozkoszy ziemskich zaś, Majewski konfrontuje się z obrazem Hieronima Boscha. Ponadto, jako reżyser często uprawia rodzaj „ożywionego malarstwa”, nie tylko poprzez kompozycję kadrów i pewien estetyczny porządek, ale też cytując i parafrazując w tekście filmowym ważne dla siebie obrazy, na przykład Tajemnicę i melancholię ulicy Giorgio de Chirico w Pokoju saren czy Zdjęcie z krzyża Rogera van den Weydena w Szklanych ustach. Niekiedy bezpośrednich odwołan do malarstwa nie znajdziemy wcale (casus Wojaczka), lecz i tak zaliczymy Majewskiego do „malarzy ekranu”. Bardziej jednak interesuje mnie jego twórczość literacka; dziedzina filmowa będzie raczej kontekstem dla relacji malarstwo - literatura, co nie znaczy, że tylko tak należy ją traktować.

Również w twórczości literackiej Lech Majewski stosuje bardzo różne strategie obecności malarstwa w danym utworze. Może to być postać, której pisarz zwyczajnie poświęci tekst prozatorski, jak w noweli $B a$ squiat. Nowojorska opowieść filmowa. Kiedy indziej bohaterowie jego powieści patrzą na rzeczywistość z perspektywy konkretnego obrazu, jak ma to miejsce w Metafizyce, gdzie ich działania uzależnione są od interpretacji Ogrodu rozkoszy ziemskich. Czasem będą to notatki i krótkie eseje, jak w Oficjalnym centrum świata, gdzie autor omawia wybrane aspekty twórczości interesujących go malarzy, m.in. Leonarda da Vinci, Pabla Picassa czy Arnolda Böcklina. Może się też zdarzyć, że dramaturgizując ich role, powierzy im zadania na drugim planie powieści, jak ma to miejsce w Pielgrzymce do grobu Brigitte Bardot Cudownej, albo też wprowadzi elementy dyskursu naukowego, związane m.in. $\mathrm{z}$ historią sztuki, jak w Hipnotyzerze czy wspomnianej Metafizyce. Już choćby z tego wstępnego wyliczenia można się zorientować w rodzaju i skali zainteresowań malarskich Majewskiego, a także w jak różnorodnych gatunkach literackich się pojawiają. Powrócić teraz trzeba do początku i zapytać o nadrzędną inspirację dla tej twórczości, a więc o Leonarda da Vinci i jego poglądy na sztukę. 
Powiedzieć należy, że to nie w wymiarze estetycznym malarstwa autora Mony Lizy znalazł Majewski korespondujące z własnymi rozwiązania. Daleko przecież jego twórczości do „wzniosłego i niezachwianego naturalizmu"1, cechującego obrazy Włocha. Aby zobaczyć to dziedzictwo u polskiego artysty, zawsze trzeba mieć świadomość jego intencji. Autor ten bowiem kreuje siebie i własną sztukę jako element wzajemnie oświetlającego się systemu odniesień nauki, filozofii i właśnie kreacji artystycznej. W praktyce polega to na równoważności różnych dyskursów oraz dialogu pomiędzy systemami znakowymi wewnątrz własnej wypowiedzi artystycznej oraz określenia się wobec zewnętrznych źródeł malarskich. Właśnie w dążeniu do uniwersalizmu, z jakim trudno się dzisiaj już spotkać, widzę najgłębszy związek polskiego twórcy z Leonardo da Vincim. Powracające tematy sztuki, jej toposy i archetypowe obrazy ujmowane są przez Majewskiego w różnych materiach i formach, często także w formie autocytatów i autorefleksji. Podobnie rzecz miała się z da Vincim. Jak zauważa Maria Rzepińska:

Mówiąc o działalności Leonarda, trzeba od razu zaznaczyć, że była ona jedynie wycinkiem jego zainteresowań, bardzo wszechstronnych, różnorakich, które umiał jednak połączyć w jakąś wielką syntezę. Jest ona najdoskonalszym przykładem renesansowego uniwersalizmu, ogarniającego nie tylko znajomość wszystkich dyscyplin artystycznych, ale także różnych gałęzi nauk - przede wszystkim przyrodniczych. Leonardo uważał, ze im pełniejsza jest wiedza o świecie i przyrodzie w ogóle, tym pełniejsza i lepsza jest sztuka².

Różnica pomiędzy nimi dotyczy sposobu na istnienie w świecie sztuki. To, co u Leonarda da Vinci było instynktownym zapewne u początków odczuciem wspólnoty sztuki i wiedzy, u polskiego twórcy zawierać będzie także pierwiastek autokreacji i autopromocji, skądinąd dzisiaj powszechnej. Jak widać ze wstępnych uwag jednym z celów tego tekstu jest, pomimo rozpiętości źródeł i tworzyw badanego materiału, zwrócenie uwagi na artystyczny i duchowy patronat twórczości Lecha Majewskiego.

Tytuł drugiego z tomików poetyckich Majewskiego - Poszukiwanie raju (1979) - zapowiada jeden z kluczowych motywów jego sztuki, najwyraźniej widoczny później - w powieściowej Metafizyce i jej filmowej autoadaptacji zatytułowanej Ogród rozkoszy ziemskich. Przywołany w tych utworach obraz Hieronima Boscha odsyła nas do tematu raju, obecnego u Majewskiego w dużej mierze za pośrednictwem dzieł malarskich. W późniejszych utworach - pisanych już prozą - osoby znanych malarzy i ich dzieła będą wpływać na postawy bohaterów Majewskiego. Zajmująca pod tym względem jest Pielgrzymka do grobu Brigitte Bardot Cudownej (1996), gdzie w wyimaginowanym, choć całkiem realnie istnie-

${ }^{1}$ M. Rze pińska, Siedem wieków malarstwa europejskiego, Wrocław 1986, s. 86.

2 Tamze, s. 85. 
jącym hotelu spotykają się na równych prawach zarówno postaci z kręgu kultury popularnej (m.in. Marylin Monroe, Liz Taylor czy członkowie grupy The Beatles), jak i te, które kojarzymy ze sztuką - Rabindranath Tagore lub malarze - Pablo Picasso i Paul Cézanne. Bohater, a zarazem narrator tej książki, traktuje ich na tych samych zasadach, co inne osoby zaludniające jego śląską biografię lat 60 . Rozdarty emocjonalnie pomiędzy przyjaciółmi z młodości a telewizyjnymi i muzycznymi idolami tych czasów (podobnie w powieści Kasztanaja; 1981) wybiera „trzecią siłę” wielkich malarzy. Z Cézannem wychodzi do hotelowego ogrodu, by podziwiać górę St. Victoire, której malarz z Prowansji poświęcił wiele studiów i obrazów. Jego obsesja związana z tym elementem krajobrazu wydaje się najbardziej przemawiać do samego Lecha Majewskiego: każe on swojemu bohaterowi spotykać tych malarzy, których powinowactwo opiera się na „niezłomnej” postawie w relacjach życie - sztuka, przez co rozumiem absolutne podporządkowanie tej drugiej. W powieści na plan pierwszy wysuwa się Picasso, nota bene spadkobierca malarza z Aix. W gruncie rzeczy Majewskiego interesuje mitologiczny wymiar postawy i sztuki dawnych mistrzów, próba uchwycenia tego, jak działa ktoś obdarzony nieprzeciętnym talentem, i jak „mieści się" z nim w życiu (dobrze to również widać $\mathrm{w}$ jego filmach o współczesnych postaciach - Wojaczku i Basquiacie). W pewnej scenie książki Majewskiego hiszpański malarz i Adam prowadzą znamienny dialog:

Patrzysz teraz na moje obrazy - powiedział wracając - a wcale ich nie widzisz.

Ty widzisz legendę, która je otacza, a nie obrazy. Zresztą wszyscy je tak widzą.

- To źle?

- To bardzo dobrze. Legenda jest najważniejsza ${ }^{3}$.

Warto jednocześnie zwrócić uwagę na charakterystyczny dla Lecha Majewskiego zabieg wpisania $\mathrm{w}$ strukturę tekstu literackiego obrazu malarskiego. W tym przypadku pisarz zainscenizował scenę jego powstania, ożywiając jeden $\mathrm{z}$ utworów Picassa. To jeszcze nie ekfraza, którą Majewski również się posługuje. Mamy tu raczej do czynienia z sytuacją, o której Hans Holländer pisał, że jest sztuką opisu miejsc i sytuacji „tak jakby były one obrazami lub opisami obrazów, albo też ciągiem scen filmowych"4. Czytelnik staje się świadkiem sceny erotycznej, a jednocześnie jej uwiecznienia na płótnie. W Pielgrzymce... wykorzystuje Majewski także weneckie Biennale Sztuki jako przestrzenie do refleksji nad Burza Giorgione. Zdziwiony narrator mówi:

3 L. Majewski, Pielgrzymka do grobu Brigitte Bardot Cudownej, Kraków 1996, s. 154.

${ }^{4} \mathrm{H}$. Holländer, Literatura - malarstwo - grafika, tłum. K. Lukas, w: Ut pictura poesis, pod red. M. Skwary i S. Wysłouch, Gdańsk 2006, s. 208. 
Jak można zawrzeć kosmos w małym prostokącie. Prostokącie szerokim na siedemdziesiąt trzy i wysokim na osiemdziesiąt dwa centymetry? W małym pejzażu z burzą, kobietą i żołnierzem ${ }^{5}$.

Łatwo zauważyć, że w tym miejscu narrator wyraża opinię autora powieści. Komentarz autorski pozwala na uchwycenie motywu, wokół którego rozwija się temat i przebieg dialogu ze sztuką. W tym przypadku Burza to coś więcej niż jakieś inne arcydzieło włoskich muzeów. Dla Lecha Majewskiego spotkanie $\mathrm{z}$ dziełem Giorgione ma charakter inicjacyjny. Wielokrotnie podkreślał, że źródłem jego studiów nad sztuką i kariery artystycznej było odkrycie związku między tym obrazem a kinem:

Na mnie jednak - mówi w jednym $\mathrm{z}$ wywiadów - działało stare malarstwo: stałem przed Burzq Giorgione i zdałem sobie sprawę, że jest w niej podobny klimat, który istnieje w Powięhszeniu Antonioniego. To był dziwny przeskok myślowy, ale bardzo brzemienny w skutki dla mlodego czlowieka w okresie performatywnym, bo równocześnie ze zdaniem na Akademię Sztuk Pięknych, zdałem na reżyserię do Szkoly Filmowej6.

Jeśli „widzenie” Majewskiego skonfrontujemy $\mathrm{z}$ teorią widzenia E. Gombricha, to okaże się, że ów „przeskok myśli” jest efektem określonej sztuki malarskiej, techniki budowania sceny przedstawienia.

Przenosimy wzrok z postaci na krajobraz, który wypełnia większą część niewielkiego płótna - mówi Gombrich - znów wracamy do postaci i odnosimy wrażenie, że w przeciwieństwie do swych poprzedników i artystów mu współczesnych, Giorgione nie malowal rzeczy i osób, by rozmieścić je w przestrzeni obrazu, ale że naprawdę uważał, iż przyroda, ziemia, drzewa, światło, powietrze, chmury $\mathrm{i}$ istoty ludzkie $\mathrm{z}$ ich miastami i mostami tworzą jedność. $\mathrm{W}$ pewnym sensie był to niemal równie duży krok do przodu, jak odkrycie praw perspektywy. Od tego czasu malarstwo przestało być jedynie rysunkiem, na który nałożono kolor. Było sztuką $\mathrm{z}$ własnymi tajemniczymi prawami i środkami ${ }^{7}$.

Być może Majewski rozpoznał u Giorgione bliskie sobie dążenie do tego, aby w dziele sztuki z calą mocą i przekonaniem umieszczać człowieka jako naturalny, niezbywalny element widowiska, które - niezależnie od rozmiarów i materii - zawierać będzie choćby sugestię tak pożądanej kompletności zarówno $\mathrm{w}$ aspekcie reprezentowania Uniwersum, jak i wyrażenia go poprzez symbole. Stosuje też Majewski deskrypcję Burzy, ale ekfraza jest dla niego zawsze środkiem służebnym i raczej punktem wyjścia do dalszych rozważań nad charakterem dawnego i współczesne-

${ }^{5}$ L. Majewski, op. cit., s. 193-194.

${ }^{6}$ L. Majewski, Sztuka, czyli cudowność doświadczenia zwanego życiem, rozm. T. Gil, H. Gil, J. Sendej, Listopad 2002, www.venedi.com

7 E.H. Gombrich, O sztuce, tłum. M. Dolińska, I. Kossowska, D. Stefańska-Szewczuk, A. Kuczyńska, Warszawa 1997, s. 329-331. 
go malarstwa. Opis obrazu jest interpretacją i jako taki prowadzi do uogólnień. Majewski zdaje sobie sprawę, w jakich czasach żyje i tworzy, próbując zintegrować związane z tym ambiwalentne doznania. Jego narrator powiada:

\begin{abstract}
Malarstwo żyje i to dość jawnie, ale jakimś innym, obcym mi życiem. Życiem nie mającym nic wspólnego $\mathrm{z}$ atramentem zieleni, z Tempesta, którą można było wycisnąc jak owoc granatu. Jest stalowe, plastykowe i nie-organiczne. Podziwiam jego silę, ale pozostawia mnie ona na zewnątrz; nie pozwala zagubić się w sobie, penetrować. Przed Giorgionem mógłbym stać kilka tygodni, wciąż znajdując nowe detale, przed Lichtensteinem kilka minut ${ }^{8}$.
\end{abstract}

Majewski jako pisarz nigdy nie przestaje być historykiem i krytykiem sztuki, co daje mu przede wszystkim świadomość własnego miejsca w historii form artystycznych. Wyraża to zarówno na poziomie wewnątrztekstowym, poprzez liczne komentarze - wtrącenia odautorskie, jak i okołotekstowym, w formie licznych wywiadów, które są dla artysty innym miejscem przekazu własnych koncepcji sztuki. Wystarczy porównać cytowany fragment wywiadu na temat inspiracji Burzq z wypowiedzią narratora Pielgrzymki...:

Tajemnica zieleni Giorgiona była tajemnicą parku Powiększenia. I jak owa błyskawica rozświetlająca Tempestę przeniknęła mnie iluminacja - gdyby Giorgione żył, robiłby teraz filmy, takie jak Powiększenie, wciąż pozostając na płótnie w krainie cieni ${ }^{9}$.

W ten sposób twórca Angelusa potwierdza świadomość zadań i celów swojej twórczości, ale też ujawnia chęć odegrania roli, jaką sam wyznaczył sobie w społecznym obszarze kultury.

Wśród szczególnie bliskich Lechowi Majewskiemu malarzy, znajdujemy w Pielgrzymce... postać Hieronima Boscha, któremu poświęcił osobną powieść i film. Tutaj jest on „reprezentowany” przez obraz Łódź głupców. W hotelowej bibliotece bohater spotyka młodą kobietę studiującą Boscha. Próbuje mu ona wyjaśnić sens obrazu, mówiąc o pomieszaniu zmysłów, które prowadzi do szaleństwa, powołując się na Statek szalonych Sebastiana Brandta. Czy niewiedza jest zatem stanem, którego nie da się przekroczyć, a bohaterowie utworu zostali umieszczeniu w hotelu niczym postaci płynące łodzią w obrazie Boscha? Majewski pozostaje w sferze sugestii, jednak w finale utworu dodatkowo wzmacnia pesymistyczny wydźwięk obrazu przez podkreślenie mocy historii i jej wpływu na bohaterów. Sztuka nie pomogła całkowicie rozwiązać problemów, zmuszając bohaterów do ucieczki w fantastyczny świat przestrzeni kosmicznej (podobny szkielet powieściowy znajdujemy w Metafizyce). Sztu-

${ }^{8}$ L. Majew ski, Pielgrzymka do grobu Brigitte Bardot Cudownej, op. cit., s. 195-196.

9 Tamże, s. 196. 
ka może jedynie wskazać kierunek, w jakim należy podążać, albo też wykreować człowieka w świecie poddanym upływowi czasu.

Tym razem zainteresowanie twórczością Boscha jest u Majewskiego związane z symboliką Ogrodu rozkoszy ziemskich. Bohaterka powieści (Bea) nie tylko studiuje ten obraz, ale też potrafi namówić towarzyszącego jej w ostatnich miesiącach życia mężczyznę (Louis) do intelektualnego i zarazem fizycznego wcielenia $w$ czyn scen i idei w nim zawartych (rezultat wspólnych analiz). Oboje odnajdują ślady zaszyfrowanych zwykle u Boscha znaków i symboli, więc i miasto powieściowe widziane $\mathrm{w}$ tym kontekście jest prywatnym ogrodem rozkoszy, tyle tylko, że zgodnie $\mathrm{z}$ kulturową tradycją, staje się jednocześnie świadkiem zagłady. U kresu egzystencji bohaterkę czeka śmierć. Tym, co pozostaje po związku Luisa i Bei jest zapis na taśmie filmowej, która posłużyła za pamiętnik. Obraz Boscha, wskazówki, które tam znalazła Bea (a jest historykiem sztuki), a także mnogość wytworów ludzkiej nauki i sztuki, udowadnia, że przynajmniej one pozwalają okiełznać chaos doczesności. Bohaterom - dość niespodziewanie - pomogła $\mathrm{w}$ tym sztuka filmowa. Pisarz rozwija tu zabiegi znane już z poprzedniej powieści Pielgrzymka do grobu Brigitte Bardot Cudownej: na szeroką skalę stosuje ekfrazę, korzysta z pomysłów interpretacyjnych obrazu znanych badaczy (np. Wilhelma Fraengera10) oraz znajduje szczególną analogię między malarstwem a jego współczesnym odpowiednikiem, jakim jest sztuka filmu. Nowością jest tu wprowadzanie scen $z$ dzieła Boscha poprzez zabiegi performatywne, minihappeningi i technikę filmowania (Majewski antycypuje $\mathrm{w}$ ten sposób własną adaptację Metafizyki).

W samej kompozycji omawianej prozy jest już umieszczone dzieło filmowe. Opowiadanie bowiem oparte jest na serii krótkich obrazów przypominających szybko montowane ujęcia filmowe, a przede wszystkim niemal na każdym etapie narracji pojawia się kamera, która często pośredniczy w opisie (np. filmowanie obrazu wraz z komentującą go bohaterką, czy rejestrowanie tego, co się aktualnie wydarza). Jednak Majewski to nie tylko poeta czy prozaik, ale także eseista i kronikarz, o czym świadczy jego tom Oficjalne centrum świata (1998), noszący podtytuł Malarze, gwiazdy, miasta, obrazy11.

To rodzaj pamiętnika lub notatnika, w którym autor zawiera własne refleksje na temat sztuki i kultury współczesnej, na które patrzy z perspektywy artysty-nomady, wędrującego w trakcie realizacji kolejnych projektów z Europy do Stanów Zjednoczonych. Obok wspomnianego dia-

10 W. Fraenger, Hieronim Bosch, tłum. B. Ostrowska, Warszawa 1990.

11 L. Majewski, Oficjalne centrum świata. Malarze, gwiazdy, miasta, obrazy, Gdańsk 1998. 
riusza Majewski napisał również zarys scenariusza, a zwłaszcza nowelę zatytułowaną Basquiat. Nowojorska opowieść filmowa (1997)12. W Jean-Michelu Basquiacie polski autor zobaczył nie tylko zdolnego malarza i poetę amerykańskiego neoekspresjonizmu lat 80. dwudziestego wieku, ale zwłaszcza twórcę dysponującego takim rodzajem energii i odwagi w oglądzie współczesnego świata, który pozwalał mu w sztuce dotknąć niemal każdego jego przejawu związanego z ludzką działalnością. Majewski wyjaśnia w pewnym momencie, kim był nowojorski artysta, charakteryzując go poprzez znamienne zestawienie „Da Vinci kontra Basquiat":

[...] uderzyło mnie kilka rysunków, które co prawda w sposób prostacki i dziecinny, niemniej jednak korespondowały ze stronicami kodeksu Leonarda. Kartki papieru, które Basquiat zapełniał czymkolwiek, co przewinęło mu się pod ręką lub przed oczyma: nazwy miejscowości przepisane $\mathrm{z}$ atlasu, wykresy astronomiczne skopiowane $\mathrm{z}$ encyklopedii, nazwy lektur i broni $\mathrm{z}$ książki o historii, napis z paczki papierosów i kartonu mleka, słowa neonów, komiksów i biletów lotniczych, diagramy aparatury dźwiękowej i stacji metra, potrawy z menu i toporne kopie dwudziestopięciocentowych monet, wszystko, co każdemu przewija się przez ręce. [...] A więc Basquiat bez klękania przed autorytetem stal się współczesnym Leonardem, usiłującym dociec istoty danego mu życia i świata na kartce papieru. I był tego bezczelnie świadomy. Jedną ze swoich prac zatytułował Leonardo's Greatest Hits ${ }^{13}$.

Oprócz wyrazu fascynacji młodym malarzem, notatnik Lecha Majewskiego przynosi mnóstwo obserwacji dotyczących życia wśród obrazów. Autor dostrzega w Nowym Jorku - podobnie jak bohaterowie jego Metafizyki w Wenecji - wszechobecność oddziaływania sztuki (obrazów). Wyraża się to nie tylko w natłoku galerii, obiektów architektury, filmów czy fotografii reklamowej, słowem - całej ikonosfery tego miasta, ale zwłaszcza w autorskim poczuciu bycia elementem tego spektaklu, i potrzebą odnalezienia w nim jakiegoś porządku. Katedry, fabryki, magazyny - prawie każdy rodzaj budowli lub ich układ wydaje się pisarzowi olbrzymią, trójwymiarową kopią jakiegoś obrazu. Przykładowo:

U podnóża Tudor City jest ulica; wychodzi na ścianę, barierę, pod barierą przepaść kilku pięter. Nierzeczywista ulica, która kończy się w ścianie i tylko z perspektywy mojego budynku widać, iż pod spodem jest druga ulica, Wschodnia 40. [...] Ulica z de Chirica ${ }^{14}$.

Świat materialny odsyła zwykle autora lub narratora (vide: Metafizyka) do czegoś wyższego, uporządkowanego, poddanego jakimś regułom.

${ }^{12}$ L. Majewski, Basquiat. Nowojorska opowieść filmowa, Poznań 1997.

${ }^{13} \mathrm{~L}$. Majew ski, Oficjalne centrum świata, op. cit., s. 14-15.

14 Tamże, s. 7-8. 
Majewski pokazuje zarówno obecność sztuki dawnej w najnowszej, choć nie chce ujmować jej w kategoriach hierarchicznych i, z przyczyn oczywistych, nie wskazuje różnic pomiędzy malarzami amerykańskimi a tymi z Europy Wschodniej. Choć sam czuje się obywatelem świata, dostrzega ich odmienność w podejściu do procesu tworzenia. Swiadczy o tym m.in. jego relacja ze spotkania z gruzińskim malarzem Romanem Krihelim:

Byłem u Schnabla - zaczynam i Roman potwierdza, że wie o kim mowa i owszem, szanuje jego dokonania - a teraz jestem u ciebie. Robię film o Basquiacie i myślę o moich poprzednich filmach i widzę jedno: my, artyści ze Wschodu, nie mamy odwagi niszczyć. Oni, artyści Zachodu, niszczą bez zmrużenia oka. Julian bierze dziewiętnastowieczny obraz, skrobie na nim napis i tworzy swój obraz. Ty spędzasz dni, tygodnie i miesiące, budując parafrazy Michała Anioła, precyzyjnie dopracowane aż do bólu: ja wypracowuję każdy detal swojego filmu aż do masochistycznego wycieńczenia i przez głowę nie przeszła mi nawet myśl, że można niszczyć. Że niszczenie jest również budowaniem. A Picasso nie mógłby urodzić się na Wschodzie, gdyż nie rozwaliłby kubistyczną siekierą wyrafinowanego malarstwa Europy ${ }^{15}$.

Nawet, jeśli autor Wojaczka pozwala sobie na uogólnienie, to trudno w jego postawie nie dostrzec pewnej ambiwalencji. $Z$ jednej strony ma świadomość tradycji, $\mathrm{z}$ drugiej natomiast nie unika chęci zrozumienia i docenienia sztuki „nowych amerykańskich barbarzyńców” - Schnabla czy Basquiata. Ich także chce wpisać w wielki lańcuch pokoleń malarzy, którzy uczestniczą w procesie odkrywania i nazywania świata. Tymczasem powstaje pytanie: jaki obraz sztuki wyłania się z interakcji stylów: tradycyjny - Majewski, i jakie miejsce dla swojej sztuki widzi on w tej rozległej czasowo i estetycznie perspektywie?

Pełnej odpowiedzi będzie można udzielić dopiero wtedy, gdy dokładnie przeanalizuje się pod tym względem jego twórczość filmową. $W$ tym miejscu przybliżyć nas mogą do niej formy obecności dzieł malarskich, którym artysta poświęca wiele uwagi. W Oficjalnym centrum świata jest to także dziewiętnastowieczna Wyspa umarlych Arnolda Böcklina. Obraz ten, jak się zdaje, od wczesnych lat kształtował wyobraźnię Majewskiego. Dzieło niemieckiego malarza zostaje tu przywołane jako intensywne przeżycie $\mathrm{z}$ młodości. Podczas jednej z wizyt u znajomych we Włoszech autor odnajduje w pamięci swe wczesne fascynacje:

Odchodzę w głąb ogrodu i przyglądam się grupie odwróconych do mnie plecami osób. Ich ciemne sylwetki delikatnie rysują się na tle mglistego miasta tlącego się ponad jeziorem. Przypominam sobie Wyspę umarlych Böcklina. Ilekroć mama zabierała mnie do ciotki Czechowskiej w Katowicach, stałem zafascynowany

15 Tamże, s. 36. 
reprodukcją tego obrazu, wiszącą w jej mrocznym mieszkaniu pod sufitem. Było to najbliższe odczucie śmierci ${ }^{16}$.

Jaki jest zatem efekt obrazu? Dzieło Böcklina jest bliskie rozumieniu sztuki przez Majewskiego w tym sensie, że daje się przez niego wykorzystać na zasadzie przekształcenia jego funkcji znaczeniowej. Obraz ten uwiódł pisarza tym, że tematycznie reprezentował ideały sztuki klasycznej, natomiast jego wartości estetyczne przynależą już do symbolizmu, do którego Majewskiemu chyba najbliżej. Pisał o tym znawca twórczości malarza, Andrzej Nowakowski, w kontekście postromantycznego modelu sztuki Böcklina:

Mówiąc o ideowym zapleczu mamy na myśli przede wszystkim kwestię niezwykle ważną, a może dla ikonografii całego ubiegłego stulecia najważniejszą: mianowicie problem samotnego człowieka wobec czasu, śmierci i Natury ${ }^{17}$.

Obraz ten, a zwłaszcza jego nastrój odnajdziemy w formie parafrazy w Metafizyce, gdzie para kochanków trafia na wenecką wyspę San Michele, o której narrator mówi, że ,jest kwintesencją wszelkich cmentarzy. Niemal teatralna, a jednocześnie rzeczywista dekoracja świata zmarłych"18. Właśnie ów aspekt teatralności czy umowności tego, co się wydarza przed oczyma narratora Majewskiego powinien być dla nas interesujący. Autor ten niezależnie od medium, jakim się posługuje, wybiera z zasobów malarstwa europejskiego obrazy charakteryzujące się figuratywnością i anegdotycznością, a następnie umieszcza je w przestrzeni powieści czy filmu. Dzięki temu całość nabiera znamion spektaklu, w którym uczestniczą „osoby dramatu”. Dotyczy to zarówno narratorów, jak i autora. Pisarz powiada przecież:

Żyć $w$ harmonii ze sobą, a nie $z$ wyspekulowaną ideą tego, co jest najlepsze... Siedzieć. Myśleć. Widzieć. Notować. Zapisywać obrazy. Obrazy. Obrazy. Obrazy $^{19}$.

Owo „zapisywanie obrazów” najpełniej realizuje się w filmie Szklane usta (2007), w którym autor inscenizuje spotkanie z fascynującymi go dziełami malarskimi - m.in. Wyspq umarlych Böcklina czy Źródtem mlodości Łukasza Cranacha - układającymi się w przypowieść o młodym poecie.

Jak już wspominałem, jedną z centralnych postaci tomu esejów Lecha Majewskiego jest malarz i poeta Jean-Michel Basquiat. Prace nad filmem o nim trwały kilka lat, ostatecznie polski twórca poświęcił mu

16 Tamże, s. 68.

17 A. Nowakowski, A. Böcklin. Chwała i zapomnienie, Kraków 1994, s. 261.

${ }^{18}$ L. Majewski, Metafizyka, Kraków 2002, s. 77.

${ }^{19} \mathrm{~L}$. Majewski, Oficjalne centrum świata, op. cit., s. 11. 
tzw. nowelę filmową. $\mathrm{Z}$ pozoru niczym się ona nie różni od tego typu zbeletryzowanych scenariuszy filmowych. Poetyka utworu jest charakterystyczna dla reprezentowanego gatunku: operuje wyłącznie krótkimi zdaniami, często w formie równoważników, narracja ma charakter zobiektywizowany, opis miejsc i zachowań postaci jest neutralny, dominują dialogi. Zawiera jednak istotne novum, które świadczy o tym, że Majewski znalazł własny sposób przekładu znaków tworzywa filmowego na literackie. Starał się po prostu nie wyzbywać w noweli aspektu wizualnego. Jak to zrobit?

Każdy rozdział Basquiata. Nowojorskiej opowieści filmowej skonstruowany jest na zasadzie analogii do filmowego ujęcia lub sceny. Zawsze zaprezentowane zostaje $\mathrm{w}$ nim miejsce akcji, postaci, ich zachowanie i rozmowy, jakie toczą. W zależności od stopnia komplikacji fabularnej rozdziału można mówić o odpowiedniości wobec ujęcia, kiedy akcja toczy się w sposób ciągły, i sceny - kiedy z kolei wewnątrz rozdziału rozgrywa się wyraźniejszy epizod. Trzeba podkreślić, że jest to tylko sugestia analogii, gdyż rozdziały noweli trudno podporządkować jednostkom znaczącym w filmie. Ale najważniejszym zabiegiem Majewskiego jest wprowadzenie do większości rozdziałów obramowanych napisów, które zwykle je otwierają. Są to wydrukowane wielkimi literami zdania-sentencje podpisane znakiem (C) i napisem SAMO (czytaj 'sejmo'). Są one odpowiednikiem tych, które Basquiat umieszczał na murach, obrazach i grafikach. Był to znak jego własności artystycznej, tyle że traktowany - co najmniej - autoironicznie. W noweli te odpowiedniki graffiti opierają się na grze słów i paradoksie, prowadząc w stronę pozornego absurdu. Przykładem mogą być: ZAPŁAĆ ZA ZUPE, ZBUDUJ FORTECE I JA PODPAL ${ }^{20}$, UŁASKAWIONY PRZEZ SWA MŁODOŚ́́ 21 oraz SAMO JAKO ALTERNATYWA DLA BIAŁYCH SCIAN22. Już choćby z tej wyrywkowej prezentacji można zorientować się $\mathrm{w}$ charakterze sztuki uprawianej przez Basquiata, występującego tu jako SAMO. Lapidarność, humor i nieoczekiwana pointa każą myśleć o haiku, lecz pod tą formą ukrywa się pewien program artystyczny i społeczny. Nie można go właściwie zrozumieć bez denotacji skrótu SAMO. Wyjaśnia go w rozmowie z Jerzym Illgiem sam Majewski:

Basquiat i Al Diaz podpisywali się pod tymi inskrypcjami OSAMO, co jest skrótem od SAME OLD SHIT, a czyta się 'sejmo' - starzy Murzyni uwielbiają robienie ze wszystkiego skrótów ${ }^{23}$.

${ }^{20}$ L. Majewski, Basquiat, op. cit., s. 35.

21 Tamże, s. 44.

22 Tamże, s. 80.

${ }^{23}$ L. Majewski, Zbuduj fortecę i podpal ja, rozm. J. Illg, w: L. Majewski, Basquiat, op. cit., s. 9. 
Wynika z tego, co następuje. Po pierwsze, Basquiat odwołuje się do praktyk stosowanych przez grupę tożsamą z nim społecznie i rasowo, a po drugie, młody artysta dokonuje autodemaskacji swoich poetycko-graficznych działan, sygnowanych przez Basquiata-prowokatora. Nowojorski malarz anektuje otaczającą go przestrzeń: tą realną, a także symboliczną, poddaną prawidłom sztuki, a zarazem burzy iluzję, że jego autorskie graffiti to właśnie sztuka. Również podpis w rzeczywistości nie unieważnia jego dzieła, lecz ujmuje je w autoironiczne ramy. Komunikat ten dociera jednak do nielicznych. To chyba ta dezynwoltura ujęła Lecha Majewskiego u Basquiata, podobnie jak u innych znanych mu artystycznych życiorysów.

To, co działo się z jego życiem - wyjaśnia dalej w cytowanej rozmowie - w trakcie tych siedmiu lat sławy, przypomina mi to, co czytałem kiedyś u Kąkolewskiego, który opisywał, jak z Frykowskim jeździł po Łodzi i na szwaczki wychodzące z pracy wyrzucał pęki pieniędzy. Nasuwają się także porównania z Jamesem Deanem, z Wojaczkiem, z Cybulskim, z osobowościami, które wypróbowują granice wolności - aż do śmierci. Równocześnie uważam, że Basquiat był wielkim artystą. Dał mi dużo siły. Kiedy chodziłem do Windsoru i oglądałem kodeksy Leonarda, mialem poczucie marności; świadomość, że mierzę niecaly milimetr - a Basquiat poprzez swoje prace powiedzial mi: Ten proces toczy się ciągle, zobacz co ja robię, ja też siedzę i odkrywam świat ${ }^{24}$.

Basquiat dla Majewskiego to artysta, który - choćby intuicyjnie chce rezonować $\mathrm{z}$ rzeczywistością, opisać ją, skatalogować, dać jej reprezentację w dziele sztuki, dążąc do maksymalnie rozległej perspektywy. To niespodziewany amerykański pośrednik między nim a Leonardo da Vincim, który również wszystko potrafi narysować. Wedlug Marii Rzepińskiej

Leonardo przyznaje rysunkowi prawo do kreowania ksztaltów, a nie tylko odtwarzania. Rysunek jest dla niego środkiem demonstracji praw naukowych, ale też wyzwoleniem wyobraźni, możliwością najwszechstronniejszej i najswobodniejszej wypowiedzi. Posługuje się nim w celu unaocznienia swych tez roboczych i wynalazków technicznych, ale także do wyrażania najbardziej intymnych przeżyć swego umysłu i psychiki ${ }^{25}$.

Podobne cechy odnalazł Majewski u Jean-Michela Basquiata, nowojorskiego barbarzyńcy w ogrodzie sztuki, w którym sam zawsze czuł się swobodnie, tym pewniej, jeśli mógł i dzisiaj znaleźć w nim figurę tożsamą z jego własnym sposobem patrzenia na sztukę i rzeczywistość. Figura taka stała się już powracającym motywem jego twórczości: to zwykle

24 Tamże, s. 16.

${ }_{25}$ M. Rzepińska, Leonarda elementy nauki o malarstwie, w: Leonardo da Vinci, Traktat o malarstwie, tłum. M. Rzepińska, Gdańsk 2006, s. 101. 
malarz lub poeta, często dążący do samozagłady, jak Wojaczek czy właśnie Basquiat.

Inną ciekawą perspektywą w tej twórczości będzie „sztuka anamnezy", czyli proces odkrywania tego, co zapomniane lub ukryte w rzeczywistości, a możliwe do przypomnienia poprzez znalezienie znaczenia znajdujących się w niej obiektów i przedmiotów sztuki. W ten sposób odczytują świat bohaterowie Metafizyki, taką strukturę posiada też Hipnotyzer (2003), powieściowy thriller, którego akcja rozgrywa się w Wenecji. Sensacyjna intryga osnuta jest wokół działań tytułowej postaci. El (On) siłą wzroku i umysłu sprowadza do weneckiego pallazzo grupę osób ze środowiska naukowego, która ma poprzez dyskusję rozwiązać zagadkę swego uwięzienia. Pałac pokryty jest symbolicznymi rysunkami oraz zawiera przedmioty, które mogą być wskazówkami dla poszukujących. Powieść ujęta jest w kształt zapisków i notatek, pozostawionych przez jednego $\mathrm{z}$ więźniów. Jego historię poznajemy z pewnym trudem, gdyż jej część spisana jest pismem izometrycznym. Bohater przyznaje się do pewnej inspiracji.

Gdy miałem jedenaście lat, zobaczyłem film o Leonardzie da Vinci, do tego stopnia zaintrygował mnie piszący lewą ręką, od prawej strony kodeksu do lewej, że postanowiłem posiąść tę umiejętność [...] A przy tym dokonałem niezwykłego odkrycia: wywrócona pisownia pozwoliła lepiej skoncentrować się na sensie słów - przestalem ulegać łatwym automatyzmom znaczeñ ${ }^{26}$.

Majewski przywołuje kolejny raz autora traktatu o malarstwie nie tylko dla graficznej komplikacji powieściowego tekstu. Da Vinci jest mu potrzebny w charakterze pioniera łączącego w swej pracy dyskurs naukowy $i$ artystyczny. Ten pierwszy zazwyczaj jest u Majewskiego ubrany w kostium popularnego gatunku, np. melodramatu w Metafizyce i powieści sensacyjnej w Hipnotyzerze. Pod nim kryją się warstwy - nieraz bardzo skomplikowanych - znaczeń. W Hipnotyzerze będzie to między innymi nawiązanie do gnostyckiej zasady, która kazała zasłaniać istotę rzeczy przed profanami za pomocą szyfru. W interesującym nas aspekcie powieść ta jest też popularnym wykładem na temat malarstwa symbolicznego, omawiającym założenia kodów dawnej sztuki. Tyle tylko, że autor ten zwykle posługuje się tak dużym uogólnieniem, iż nieco je trywializuje. Wspólna droga nauki i sztuki doczekała się już wielu traktatów hermetycznych: pisarz chce dać czytelnikowi iluzję obcowania z jednym $\mathrm{z}$ nich. W ostatecznym rozrachunku warstwa fabularna utworu koegzystuje z eseistyczną poprzez ujawnienie wysokiego stopnia autorefleksji autora. W Hipnotyzerze Majewski swoim zwyczajem wygłasza artystyczne credo za pośrednictwem jednej z postaci. Tym razem polemizuje ze słyn-

${ }^{26}$ L. Majew ski, Hipnotyzer, Poznań 2003, s. 91-92 
ną tezą Ludwika Wittgensteina o granicach świadomości wyznaczonych przez granice języka. W liście do niego porte parole autora postuluje:

Obrazy niosą bogactwo znaczeń, i to symultanicznie, przeto ktoś, kto na nie spogląda, rzadko wie, jak wyrazić swoje odczucia, jak się wysłowić, czyli posłużyć językiem. Ma pan całkowitą rację, mówiąc, iż język jest linearny, ale nie bierze pod uwagę, że stwarza nielinearne obrazy. Obraz jest bogaty swą jednoczesną wspótistnościa odczuć i dlatego, jeżeli szukać już analogii, odpowiada wyższej matematyce pola i macierzy - stwarza pola znaczeńn ${ }^{27}$.

Podsumowując powyższe rozważania, zapytam nieco inaczej, posługując się początkową metaforą: na czym polega kreacja Lecha Majewskiego jako współczesnego odpowiednika Leonarda? Sądzę, że on wykorzystuje malarstwo, literaturę, film, operę, wideoinstalacje czy inne media do zbudowania współczesnego ogrodu sztuk, będącego rodzajem raju. Ta utopia jest realizowana przez Majewskiego na dwa sposoby. Pierwszy to alegoria raju, rozumiana jako motyw krążący w całej jego twórczości. Będzie to na przykład Wenecja z Metafizyki i Ogrodu rozkoszy ziemskich; zawierający różne wymiary czasoprzestrzenne Hotel z Pielgrzymki do grobu Brigitte Bardot Cudownej czy choćby okultystyczna śląska gmina w Angelusie. Drugi sposób rozumienia tej utopii odnosi się do nieograniczonego w gruncie rzeczy spektrum multimedialnego, z jakiego korzysta artysta, co prowadzi go do realizacji marzenia o syntezie sztuk. Majewski w ten sposób na nowo definiuje pojęcie artysty, który tworzy odmienny rodzaj sztuki elitarnej, zawierającej w sobie m.in. doświadczenia popkultury, i gdzie liczy się także znajomość kulturowej, filozoficznej i naukowej tradycji, rozumienie poetyki różnych mediów i swoboda w posługiwaniu się nimi. Ostatecznie Lech Majewski stara się ogarnąć język niemal wszystkich mediów; czy jednak nie przypomina $\mathrm{w}$ tym pewnego renesansowego artysty, którego spadkobiercą stara się być?

27 Tamże, s. 178. 